\title{
Recovery of the Bird Community after a Mine Spill and Landscape Restoration of a Mediterranean River
}

\author{
Diego Ontiveros, ${ }^{1,2}$ Rocío Márquez-Ferrando, ${ }^{1}$ Juan R. Fernández-Cardenete, ${ }^{1}$ Xavier Santos, ${ }^{3,4}$ \\ Jesús Caro, ${ }^{1,5}$ and Juan M. Pleguezuelos ${ }^{1}$
}

\begin{abstract}
In Mediterranean areas, river systems are key for maintaining regional biodiversity by providing a high diversity of habitats. We studied bird community recovery for 9 years (2001-2009) during landscape restoration and Guadiamar Green Corridor establishment in the area affected by the Aznalcóllar mine spill (SW Spain, 1998). One year following plant restoration (3 years after the spill), values for $\alpha$ - and $\beta$-bird species diversity were high, sooner than reported for similar restoration processes elsewhere. Species richness, ecological diversity, and abundance increased only slightly in the following 8 years. Overlap between communities in sequential years, measured by similarity indexes, increased throughout the study period to about $70 \%$ during final survey years, and most
\end{abstract}

\section{Introduction}

In April 1998, Spain experienced its largest environmental pollution accident (Grimalt et al. 1999) when tailings from the Aznalcóllar mine containing zinc, lead, copper, antimony, cobalt, thallium, bismuth, cadmium, silver, mercury, manganese, and arsenic in a $6 \times 10^{6} \mathrm{~m}^{3}$ sludge were released into the Agrio and Guadiamar Rivers and adjacent floodplains. These tailings, varying in width from 500 to $1,000 \mathrm{~m}$, flowed $62 \mathrm{~km}$ from the mine to Doñana National Park, polluting 4,634 ha of floodplains, and covering agricultural lands, riparian vegetation, and marshes. Although active riparian restoration occurs frequently in degraded Mediterranean habitats, only little information is available regarding the efficacy of habitat restoration for reestablishing natural communities in this geography (Lindenmayer et al. 2010; Meek et al. 2010).

\footnotetext{
${ }^{1}$ Departamento de Biología Animal, Facultad de Ciencias, Universidad de Granada, E-18071 Granada, Spain

2 Address correspondence to D. Ontiveros, email dontive@ugr.es

3 Departamento de Biología Animal, Avenida Diagonal 645, Universidad de Barcelona, E-08028 Barcelona, Spain

${ }^{4}$ CIBIO, Centro de Investigação em Biodiversidade e Recursos Genéticos, Universidade do Porto, Campus Agrário de Vairão, 4485-661 Vairão, Portugal

${ }^{5}$ Instituto de Investigación en Recursos Cinegéticos (IREC, CSIC-UCLM-JCCM), Ronda de Toledo, Ciudad Real, Spain
}

breeding bird species present before the accident again inhabit the area. Only 5 years after the mine accident, bird communities in the restored site were similar in species richness, abundance, and diversity to an unaffected reference site; redundancy analysis demonstrated that bird communities were also similar between the reference river and the Guadiamar. Despite the severity of the mine accident, our results suggest a swift recovery of the bird community. We attribute this success to the rapid restoration of habitat availability and the resilience of the birds. This long-term study contributes to our limited knowledge of bird species response to habitat restoration following toxic spills in Mediterranean habitats.

Key words: Aznalcóllar mine spill, bird communities, landscape restoration, riparian corridor.

Immediately following this disaster, compulsory purchase of the affected area by the Regional Government of Andalusia was followed by mechanical removal of tailings (1998-1999) and rehabilitation of natural vegetation (1999-2001). Because of sludge toxicity, traffic in the affected area was restricted to clean-up and reforestation personnel (PICOVER 2003). The area was later designated the Guadiamar Green Corridor, a protected connector between two large natural areas, the Sierra Morena in the north and Doñana National Park in the south (Fig. 1). Populations of the threatened Iberian species Aquila adalberti and Lynx pardinus occur in this area.

Studies regarding reestablishment of some taxa affected by the spill are available (Solà et al. 2004; Cárdenas \& Hidalgo 2006; Luque et al. 2007; Márquez-Ferrando et al. 2009), but the response of the bird community has not yet been documented. Because a large number of bird species (approximately 143) use these areas during migration and for nesting, this impact analysis provides valuable data regarding the restoration of bird communities. In this study, we evaluate the recovery process of the bird community at the spill site by comparing the current bird fauna with those present before the mine spill and in an unaffected river and examining the temporal variation in avian richness, abundance, and diversity over a 9-year period. 


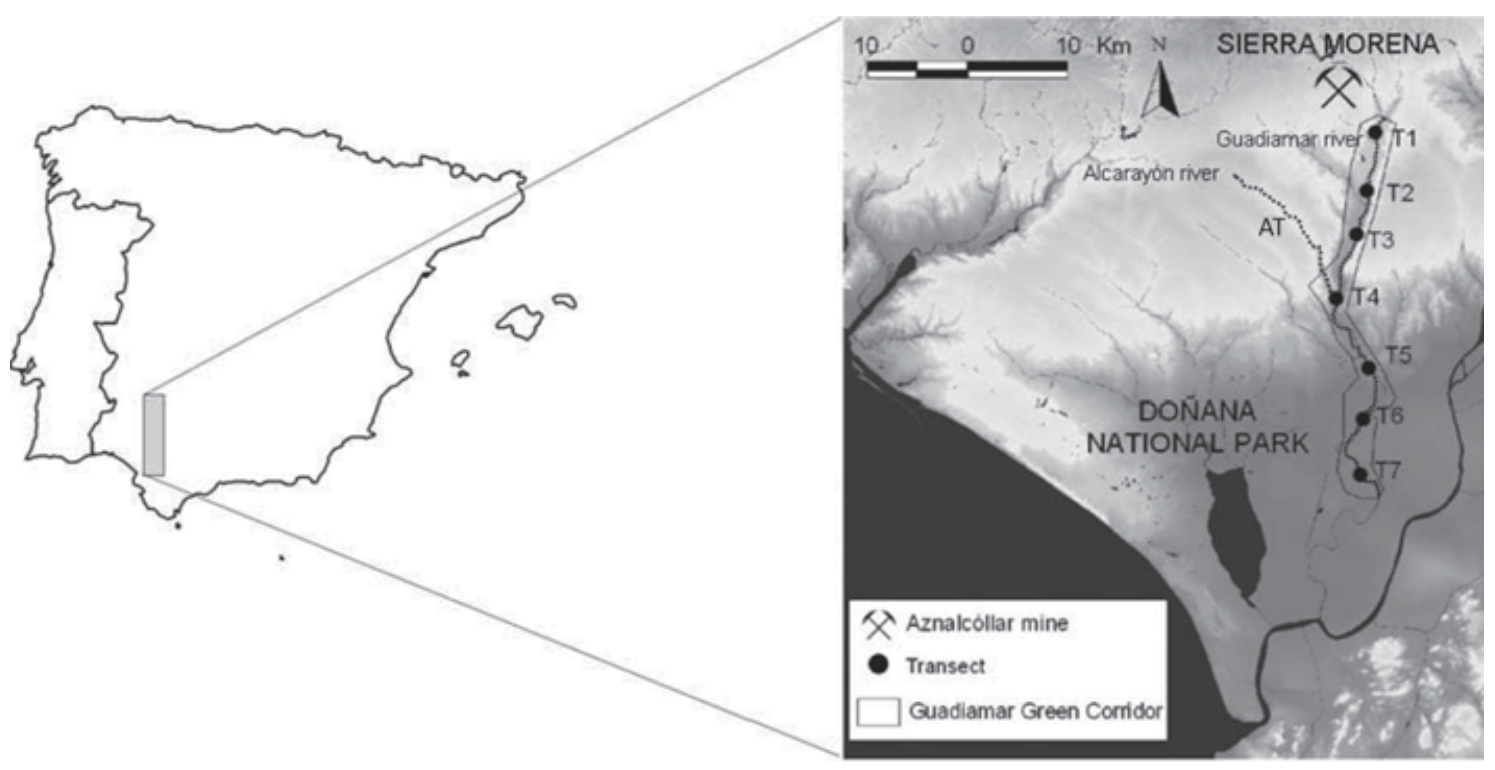

Figure 1. Iberian Peninsula (left) and detailed map of the study area (right). Small circles represent transect locations for bird censuses along the Guadiamar Green Corridor. AT, Alcarayón river transect (reference site).

\section{Methods}

\section{Study Area}

The Guadiamar River, a major tributary of the Guadalquivir River, is located in the southwestern Iberian Peninsula (Fig. 1). The climate is Mediterranean with an Atlantic influence, characterized by mild winters (mean January temperature $7.1^{\circ} \mathrm{C}$ ) and hot summers (mean July temperature $26.9^{\circ} \mathrm{C}$ ). Most of the annual rainfall (mean $646.3 \mathrm{~mm}$ ) is concentrated in winter, with a dry season in summer (data of 30-year standard meteorological averages from the Sanlúcar la Mayor weather station).

In the Guadiamar Green Corridor (62 km long and averaging circa $500 \mathrm{~m}$ wide), two landscape units are clearly differentiated. One is the 10-m wide riverside belt of gallery forest, which was conserved during the restoration process. The other is the floodplain, which was occupied by crops and dehesas (managed grasslands with isolated Quercus trees) and was revegetated in the area contaminated by the spill after cleanup.

Vegetation along the upper and middle part of the corridor, prior to the disaster, was composed of an evergreen oak forest (Quercus rotundifolia) in many places transformed into dehesas. Accompanying species were Olea europaea, Quercus coccifera, Pistacia lentiscus, Chamaerops humilis, Cistus albidus, and Rosmarinus officinalis as shrubs, and Brachypodium distachyon and Trifolium scabrum as grasses. In wetter areas, some Fraxinus angustifolia and Crataegus monogyna appeared. Meanwhile, thyme (Timbra capitata) and other shrubs (e.g. R. officinalis) covered degraded areas. Some patches of eucalyptus (Eucalyptus globulus), planted for timber, were present, and a significant surface area of the middle part of the corridor was covered by olive tree plantations. Along the riverside, the riparian vegetation was composed of poplar (Populus alba), ash (F. angustifolia), elm
(Ulmus minor), and willow (Salix alba), which was 5-10 m wide and 10-20 m high. In the river stretches with less moisture, trees were replaced by tamarisk (Tamarix gallica) and oleander (Nerium oleander), but when banks flooded, rushes (Scirpus lacustris and Juncus articulates) appeared. In the lower part of the corridor, marshlands were dominated by T. gallica (the only tree in the less flooded areas), glassworts (Salicornia sp.), almarjo (Artrhocnemum macrostachyum), and sedge (Scirpus maritimus) in salted soils, and the sedge (Typha dominguensis ) in deeper waters, and reeds (Phragmites australis) (see more details in Carrascal et al. 2008).

The restoration of the landscape after the disaster followed the criteria of conservation of the natural vegetation not altered by the spill, densification of previous trees and shrubs, removal of alien and cultivated species, and recovery of woody plants, shrub patches, and faunal populations, in general (PICOVER 2003; Carrascal et al. 2008). By 2008, 10 years following the accident, the landscape in the parts of the corridor most affected by the spill (the upper and the middle parts) showed $39.4 \%$ of the surface with a canopy cover below 25\%, $24.7 \%$ of the area with a canopy cover between 25 and 50\%, 14.8\% of the area with a canopy between 50 and $75 \%$, and $20.9 \%$ of the area with a canopy higher than $75 \%$ (riparian vegetation included; elaborated from the data in Carrascal et al. 2008).

\section{Avian Surveys}

Although bird community data from each site prior to perturbation would be ideal for comparison, without these data it is appropriate to examine unaffected (reference) sites close to affected areas for evaluating response to habitat restoration (Patten \& Rotenberry 1998). We used three strategies to analyze bird communities: (1) comparison between pre-spill and post-spill contamination; (2) analysis of temporal change 
post-spill; and (3) comparison between communities from contaminated and noncontaminated (reference) rivers.

For the pre- and post-spill comparison of breeding bird communities, we relied on the atlases of breeding birds of Spain (Purroy 1997; Martí \& Del Moral 2003) for the data on presence of bird prior to the accident. These projects did not follow our bird survey procedure, but were focused on obtaining avian species richness of geographical units $\left(100 \mathrm{~km}^{2}\right)$ similar in scale to our study area $\left(46.5 \mathrm{~km}^{2}\right)$. Although the atlases of breeding birds provide the best available data on the pre-spill avian species composition of our study area, we are unable to describe wintering bird communities.

To assess temporal change post-spill, we established seven equidistant $(8 \mathrm{~km})$ linear transects $(\mathrm{T})$ of $2 \mathrm{~km}$ (Bibby et al. 2000) parallel to the river through riparian (T1-T4) and marshland (T5-T7) habitats along the Guadiamar Green Corridor (Fig. 1). One survey was conducted per transect for each winter (15 October-15 February) and breeding (15 April-15 June) season during 2001, 2002, 2004, 2005, 2006, and 2009; all transects were surveyed between 0600 and 0930 hours on days of good visibility by an observer walking at approximately $1.5 \mathrm{~km} / \mathrm{h}$ on consecutive days. Distance between bird and observer was determined with a laser rangefinder (Bushnell Trophy ${ }^{\circledR}$; range 5-732 m, accuracy $\pm 1 \mathrm{~m}$ ) when reflective objects were available and by eye when necessary. We assumed that the probability of detecting a particular species was not different among transects or between seasons; swifts and swallows could not be counted and were included only in our determination of species richness. For a more accurate abundance estimate, observations were truncated at the distance detection frequency that is independently declines sharply for each species (Bibby et al. 2000).

Data from the Alcarayón River (10 km W of the Guadiamar River, untouched by the spill; Alcarayón River transect; Fig. 1), surveyed from 2004 to 2006 using the same method we utilized for the Guadiamar River, provided a baseline for determining community disparity between rivers (Ruíz-Jaén \& Aide 2005). Only bird communities within sector T4 of the Guadiamar River were compared to those along the Alcarayón River, because at this location plant assemblages were similar on both rivers: shrubs $<4 \mathrm{~m}$ in height (oleanders, tamarisk, ivy, and blackberries) and trees (willows, eucalyptus, poplars, and alders).

\section{Data Analysis}

To assess changes in the bird community over time, $\alpha$ - and $\beta$-diversity (Magurran 2004) were computed for breeding bird communities of the Guadiamar River (Mills et al. 1991; Gaston \& Spicer 1998) using mean annual values for our seven transects. $\alpha$-Diversity, the diversity of a spatially defined unit, was measured each year in three ways: species richness (number of recorded species), abundance (individuals/10 ha), and Simpson index (inverse of $D=D={ }^{-s}{ }_{i=1} \frac{n_{i}}{N\left(\frac{n_{i}}{N}\right.} \frac{-1)}{-1)}$, where $S$ is the number of species, $n$ is the number of individuals of species $i$, and $N$ is the total number of individuals).
$\beta$-Diversity measures community resemblance in species composition and abundance between two or more spatial or temporal units and was determined for the corridor during 2001-2009 using Sørensen’s and Morisita-Horn’s similarity indexes. Sørensen's index is a qualitative measure that determines proportion of species having 2 years in common.

It is calculated by $I s=2 c / a+b$, where $a$ and $b$ are the number of the species present in each of the 2 years, and $C$ is the number of species that the 2-year period has in common. Morisita-Horn's index is quantitative, not influenced by species richness or sample size, and defined as $C_{\mathrm{MH}}=2^{-}\left(a_{i} b_{i}\right) /(d a+d b)(N a N b)$, where $N a$ is the total number of individuals in year $a, N b$ is the total number of individuals in year $b, a_{i}$ is the number of individuals for species $i$ in year $a, b_{i}$ is the number of individuals for species $i$ in year $b$, and $d a$ and $d b$ are calculated as $d a=-a i^{2} N a^{2}$ and $d b={ }^{-} b i^{2} N b^{2}$, respectively. Sørensen’s and Morisita-Horn's similarity indexes were calculated using ESTIMATES v7.5 (Colwell 2005), and index values close to 1.0 indicate high similarity between communities. Because $\alpha$ and $\beta$-diversity calculations are more reliable for breeding bird communities than for winter assemblages (Mills et al. 1991; Gaston \& Spicer 1998), we calculated $\alpha$ - and $\beta$-diversity only for breeding bird communities.

We performed single-ordering sampling-accumulation curves (Gotelli \& Colwell 2001) to avoid errors in measurement of species richness. These curves rise relatively rapidly at first and then more slowly as increasingly rare taxa are added. In a survey with a well-defined spatial scope, an asymptote will eventually be reached, implying that: (1) spatial distribution of individuals in the environment is random (Kobayashi 1982); (2) sample sizes are sufficient and assemblages being compared have been sampled uniformly (Abele \& Walters 1979); and (3) comparison of raw species-richness counts between different areas is valid (Gotelli \& Colwell 2001).

Comparisons of species composition between polluted (Guadiamar) and nonpolluted (Alcarayón) rivers used multivariate methods (CANOCO v 4.5, Ter Braak \& Smilauer 2002) to analyze predictor variable effect. Species abundance per transect was considered the response variable, and rivers (Guadiamar and Alcarayón) and sampling periods (breeding and winter seasons) were treated as predictor (environmental) variables for construction of the species-abundance matrix. Within sampling periods, we considered the data for three breeding and two winter seasons (2004-2006). The detrended correspondence analysis (DCA) is a multivariate statistical technique used to find the main factors or gradients in large, species-rich but usually sparse data matrices that typify ecological community data. The preliminary DCA showed a maximum gradient length of 2.058 (detrending by segments), suggesting lineal distribution of data (Ter Braak \& Smilauer 2002). This distribution and the abundance of zeros in the dataset dictated the use of a constrained linear-ordination method, the redundancy analysis (RDA). This analysis generates three axes: the species, the environmental, and the canonical axes, and checking canonical axes values allowed us to derive a specified number of 
synthetic variables from predictor variables that explain as much variance as possible in response variables. The canonical axes are those formed by linear combinations of the predictor variables, and the eigenvalue associated with each axis expresses the variance accounted for by the canonical axis. A Monte-Carlo test (499 permutations, unrestricted permutation structure) assessed significance of predictor variables and, following the recommendation of Ter Braak and Smilauer (2002), only axes with eigenvalues greater than the mean score of all eigenvalues combined were considered in the results.

\section{Results}

\section{Breeding Bird Communities Pre-Contamination} and Post-Restoration

Although five fewer species were located post-restoration than existed before the spill, in general, the recovery of avian diversity has been good. We counted 17,302 individual birds representing 143 bird species (98 species during breeding season) in the Guadiamar Green Corridor (Appendix) between 2001 and 2009. Prior to contamination, the breeding bird atlas indicated a total of 103 species during the breeding season. Ten species documented in the area before the mine accident were not discovered; three are nocturnal (Tyto alba, Strix aluco, and Asio otus) and outside the scope of our study design, two are species that are difficult to detect (Rallus aquaticus and Porzana pusilla), and the remaining five were originally quite scarce (Aegithalos caudatus, Clamator glandarius, Falco subbuteo, Gelochelidon nilotica, and Oenanthe hispanica). On the other hand, we found five species not previously documented from the area, in which three species are forest warblers (Appendix). No reliable information for the wintering bird community in the study area before the accident is available.

\section{Recovery of the Bird Community over Time after Restoration (Analysis of Temporal Changes)}

Individual accumulation curves for the Guadiamar Green Corridor (Fig. 2), and for the comparison between the Guadiamar River and the Alcarayón River during both breeding and winter seasons (Fig. 3), demonstrate a random ordering of pooled individuals with asymptotes achieved by 2004 in each case; from these results, we infer reliability of census data and analyses.

Between 2001 and 2009 on the Guadiamar Green Corridor, species richness increased from 45 to 71 species and diversity increased from 13.7 to 23.4 (Fig. 4). However, we found no significant correlation in either value over the years $\left(r_{\mathrm{s}}=0.75 ; p=0.08\right.$ for richness; $r_{\mathrm{s}}=0.49 ; p=$ 0.33 for diversity) because high diversity values achieved by 2002 (Fig. 4), at the beginning of the accumulation curve asymptote (Fig. 2), prevented a significant correlation. Abundance increased gradually and significantly from 67 individuals/10 ha to 102 individuals/10 ha between 2001 and 2009 ( $r_{\mathrm{s}}=0.94, p=0.04$; Fig. 4). Temporal evolution of $\alpha$-diversity among transects and among years showed no

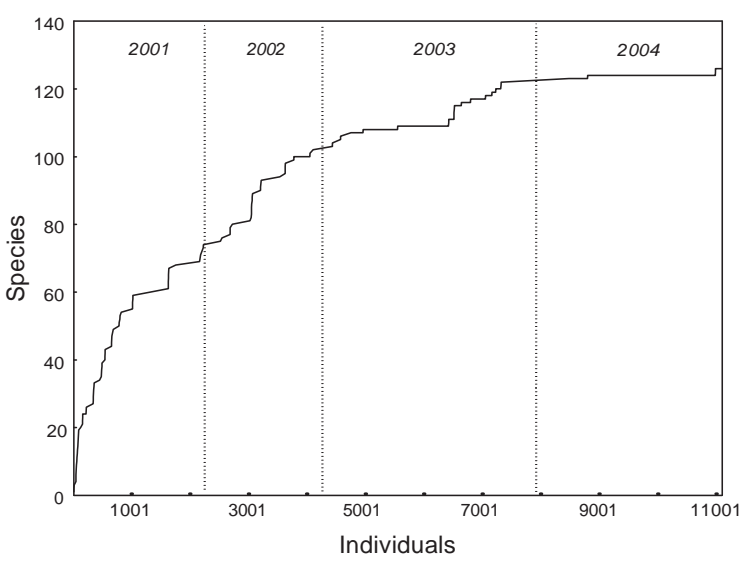

Figure 2. Individual-based accumulation curve for birds in the seven sampling areas of the Guadiamar Green Corridor from 2001 to 2004 (when the asymptote was reached).

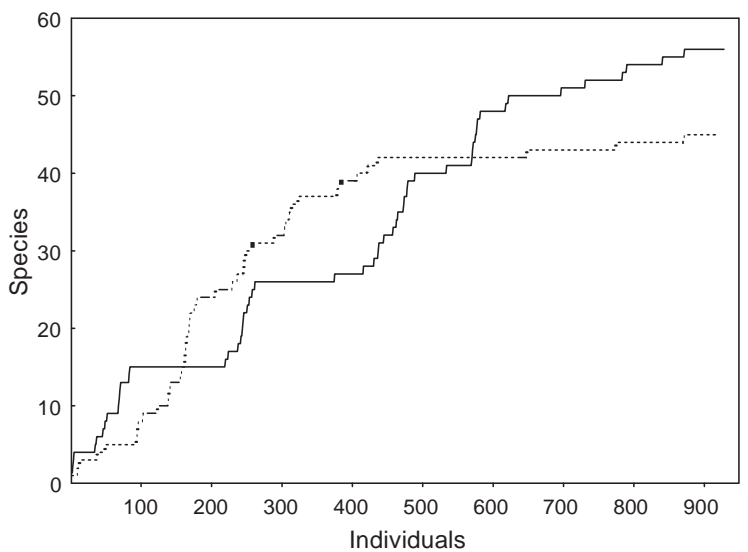

Figure 3. Individual-based accumulation curves for birds in transect 4 (solid line) of the Guadiamar Green Corridor and in the Alcarayón river transect (broken line) for the 2004-2006 period.

significant tendency when the years and transects were considered independently ( $r_{\mathrm{s}}<0.69 ; p>0.12$ in all cases).

$\beta$-Diversity results indicate that by 2009 a stable bird community composition had been reached in the restoration areas. When Sørensen's and Morisita-Horn's indexes for each survey year were compared to those for the final census year (2009), each index showed a tendency to increase over time (Table 1). Sørensen's index indicated an increase in community overlap from 60 to $76 \%$, and Morisita-Horn's index indicated an increase from 42 to $71 \%$ in community overlap (range for comparisons between first and penultimate year vs. the final year). The difference between the last 2 years was minimal for Sørensen's index (3\%) and zero for Morisita-Horn's index (Table 1).

\section{Comparison between Contaminated and Noncontaminated Rivers}

We found no differences between Guadiamar River and Alcarayón River in bird species richness, abundance, or 


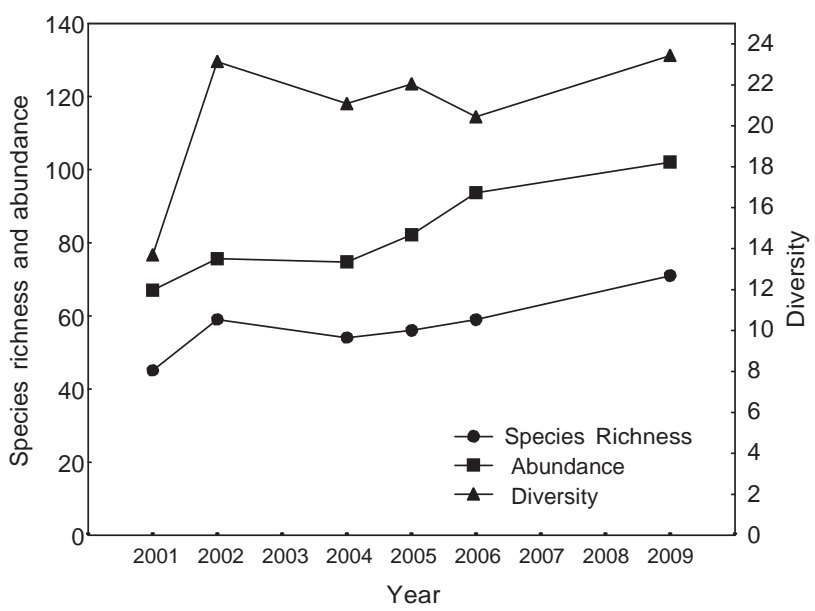

Figure 4. Species richness, abundance (individuals/10 ha), and Simpson's diversity index in the seven transects of the Guadiamar Green Corridor during the 2001-2009 period.

Table 1. Sørensen’s similarity index (bold) and Morisita-Horn’s index (italics) for breeding bird communities in the seven transects between years along the Guadiamar Green Corridor.

\begin{tabular}{ccccccc}
\hline Years & 2001 & 2002 & 2004 & 2005 & 2006 & \multirow{2}{*}{2009} \\
\cline { 1 - 4 } 2001 & $\mathrm{X}$ & $\mathbf{0 . 7 5}$ & $\mathbf{0 . 7 5}$ & $\mathbf{0 . 6 8}$ & $\mathbf{0 . 6 8}$ & $\mathbf{0 . 6 0}$ \\
2002 & 0.75 & $\mathrm{X}$ & $\mathbf{0 . 7 5}$ & $\mathbf{0 . 7 5}$ & $\mathbf{0 . 7 0}$ & $\mathbf{0 . 6 7}$ \\
2004 & 0.57 & 0.83 & $\mathrm{X}$ & $\mathbf{0 . 7 8}$ & $\mathbf{0 . 8 1}$ & $\mathbf{0 . 6 5}$ \\
2005 & 0.53 & 0.74 & 0.85 & $\mathrm{X}$ & $\mathbf{0 . 7 0}$ & $\mathbf{0 . 7 3}$ \\
2006 & 0.48 & 0.73 & 0.79 & 0.74 & $\mathrm{X}$ & $\mathbf{0 . 7 6}$ \\
2009 & 0.42 & 0.60 & 0.73 & 0.71 & 0.71 & $\mathrm{X}$ \\
\hline
\end{tabular}

Table 2. Comparisons of mean $( \pm \mathrm{SE})$ species richness, abundance, and Simpson's diversity index between breeding bird communities of the Guadiamar Green Corridor (transect 4) and the Alcarayón River (reference site) during the 2004-2006 period.

\begin{tabular}{lllcc}
\hline & $\begin{array}{c}\text { Guadiamar } \\
\text { River }\end{array}$ & \multicolumn{1}{c}{$\begin{array}{c}\text { Alcarayón } \\
\text { River }\end{array}$} & $\begin{array}{c}\text { Mann-Whitney } \\
\text { Test }\end{array}$ & $p$ \\
\hline Richness & $23.7 \pm 3.6$ & $20.0 \pm 2.0$ & 1.35 & 0.17 \\
Abundance & $76.0 \pm 10.8$ & $87.0 \pm 18.2$ & -0.83 & 0.40 \\
Diversity & $9.35 \pm 1.74$ & $7.31 \pm 1.68$ & 1.56 & 0.12 \\
\hline
\end{tabular}

diversity between 2004 and 2006 (Table 2), and the RDA corroborated these results (Table 3). Only the first two species axes (each with an eigenvalue greater than the mean of all eigenvalues combined) were considered in RDA, and each was strongly correlated with both first $(r=0.97)$ and second environmental axes $(r=0.97$; Table 3). However, the first canonical axis (determined primarily by census season) did not differ significantly from zero (Monte-Carlo permutation test; eigenvalue $=0.47 ; F$-ratio $=3.54 ; p=0.09$ ), and none of the canonical axes was significant (eigenvalue $=0.83$; $F$-ratio $=3.22 ; p=0.18$ ), implying that there were no differences between bird community species richness, abundance, or diversity of polluted (Guadiamar) and nonpolluted rivers (Alcarayón).

\section{Discussion}

Many studies have demonstrated that birds are good indicators for evaluating the success of large-scale ecosystem restoration and for stream-ecosystem bioassessment, because birds are diverse, easy to detect, and sensitive to changes in habitat structure and composition (Suárez-Seoane et al. 2002; Gardali et al. 2006). In this sense, the Guadiamar restoration plan implemented after the mine accident has been a success, at least for the bird community.

After the toxic spill, the restoration of the Guadiamar River and floodplains was intended to augment vegetation cover and complexity, and presumably favor animal-community recovery. Many case studies support the idea that habitat restoration enhances animal-community reestablishment by creating habitat mosaics that benefit the greatest number of species (Galán 1996; Nichols \& Nichols 2003). In the Guadiamar basin, all taxa with life cycles that depend on the river, and terrestrial taxa with limited dispersion capacity such as some arthropod and reptile species, were severely affected by the toxic spill (PICOVER 2003). Despite initial high values of heavy metals in the Guadiamar basin after the accident (Meharg et al. 1999), the toxic sludge was eliminated, and for these animals, species richness, abundance, and diversity increased rather slowly over time in the restored Guadiamar Green Corridor (Solà et al. 2004; Cárdenas \& Hidalgo 2006; Luque et al. 2007; MárquezFerrando et al. 2UUY). In contrast, our results indıcate that bird diversity recovered within 2 years and the community composition had stabilized within 8 years. This quick recovery of hirds relative to the nther animals mav he due to the hioh dispersion capacity and resilience of birds to human-induced disturbance (Wiens 1989).

Two years following restoration of vegetation (2002), breeding bird species richness and diversity were rather high, and the current trend suggests limited (positive) incremental change. During the first 2 years following the accident, species richness, abundance, and diversity were, however, probably low, but access to the contaminated area was restricted and no quantitative surveys are available. Currently, however, most breeding species listed in atlases of breeding birds of Spain (93.1\%; Purroy 1997; Martí \& Del Moral 2003) are present in the Guadiamar River area. Moreover, three of the five new species found during our study are warblers (Sylvia genus), species that in Mediterranean habitats select woody and structurally complex vegetation (Sylvia atricapilla, S. cantillans, and $S$. communis ), suggesting that some forest birds have also benefited from landscape recovery in the Guadiamar Green Corridor.

Animal responses to restored landscapes differ widely according to area and biogeography. Buffington et al. (2000) found that revegetation techniques used to restore a North Carolina (U.S.A) riparian habitat had little effect on bird communities 2 years following treatment. Passell (2000) reported significantly increased bird species richness, abundance, and diversity in restored Indonesian tin strip mines over 3 years, and Nichols and Nichols (2003) reported increases of 433 and $110 \%$, respectively, for species richness and abundance 7 years 
Table 3. Correlation matrices relating species axes (bird abundance), environmental axes (rivers and sample period), and individual environmental variables, from analyses generated by RDA.

\begin{tabular}{|c|c|c|c|c|c|c|c|c|}
\hline Species axis 1 & 1.0000 & & & & & & & \\
\hline Species axis 2 & 0.0302 & 1.0000 & & & & & & \\
\hline Species axis 3 & 0.0146 & -0.0288 & 1.0000 & & & & & \\
\hline Species axis 4 & 0.0593 & 0.0230 & -0.1853 & 1.0000 & & & & \\
\hline Environmental axis 2 & 0.0000 & 0.9675 & 0.0000 & 0.0000 & 0.0000 & 1.0000 & & \\
\hline Environmental axis 3 & 0.0000 & 0.0000 & 0.9001 & 0.0000 & 0.0000 & 0.0000 & 1.0000 & \\
\hline Environmental axis 4 & 0.0000 & 0.0000 & 0.0000 & 0.7001 & 0.0000 & 0.0000 & 0.0000 & 1.0000 \\
\hline Guadiamar River & -0.3325 & -0.7300 & -0.0155 & -0.1087 & -0.3434 & -0.7545 & -0.0172 & -0.1553 \\
\hline Winter 1 & 0.2631 & -0.5112 & -0.3803 & 0.4120 & 0.2717 & -0.5284 & -0.4225 & 0.5884 \\
\hline Breeding season 2 & -0.5235 & -0.0004 & 0.5950 & 0.2319 & -0.5406 & -0.0004 & 0.6610 & 0.3312 \\
\hline Winter 2 & -0.5258 & 0.1939 & -0.5790 & -0.3269 & -0.5430 & 0.2004 & -0.6432 & -0.4670 \\
\hline Breeding season 3 & 0.0004 & 0.0694 & 0.2767 & -0.1304 & 0.0004 & 0.0717 & 0.3074 & -0.1862 \\
\hline
\end{tabular}

following rehabilitation of a bauxite mining area in the Jarrah forest of southwestern Australia. Bird species richness, abundance, and diversity increased 58, 52, and 72\%, respectively, in the Guadiamar Green Corridor during the 8 years of our study.

The presence of natural areas adjacent to restoration sites is likely important to the recovery of avian communities, as they probably act as a source for colonizers (Passell 2000; Lindenmayer et al. 2010). The Guadiamar basin, partially within Sierra Morena and Doñana Park-protected areas, and surrounded by the quasi-natural dehesa agroecosystem, likely derived colonizers from these sources. Moreover, colonization response was not slower close to the dam that released the toxic sludge than it was far away, suggesting bird recolonization responded to mechanical removal of tailings and rehabilitation of natural vegetation at similar rates along the 62-km corridor.

Regardless of the successful recovery of the bird community, high levels of heavy metals are still found in the river, sustaining contamination levels hazardous to fauna (Delibes et al. 2009). This may produce potentially harmful effects on birds. For instance, birds may experience a drastic decrease in the availability of dietary $\mathrm{Ca}$ due to the $\mathrm{pH}$-related extinction of high-Ca aquatic invertebrate taxa (molluscs and crustaceans). Decreased availability of dietary $\mathrm{Ca}$ is known to adversely affect egg laying and eggshell integrity in birds, and the growth of hatchling birds (Scheuhammer 1991). Therefore, although community composition and structure were restored, it is possible that this created a sink where birds are present but cannot reproduce. This would require further study.

Rapid recovery of the bird community following Guadiamar River restoration between 2001 and 2009 was characterized by: (1) most bird species present before the accident being present after the restoration; (2) species richness, abundance, and diversity increasing rapidly during the early years of the study; (3) degree of community overlap increasing over time (similarity $>70 \%$ in the final years); and (4) only a few years after the restoration, the Guadiamar basin demonstrated similar bird diversity values and community structure to a "reference” river, uncontaminated and close to the study area. These characteristics suggest (1) rapid soil cleanup (1998-1999) and vegetation restoration (1999-2001), together supported rapid bird-population increase by augmenting perching, foraging, and nesting habitat and (2) the affected area, being long, narrow, and in close contact with natural areas and a rather well-conserved agroecosystem, potentially benefiting from a ready supply of colonizers from nearby breeding bird communities. Whether because of the narrowness of the affected area, the nature of the restoration program, or from the synergistic effect of both, revitalization of the bird community following landscape restoration met the objectives of environmental managers for the Guadiamar Green Corridor. The recovery plan design implemented for the Guadiamar Green Corridor appears, at least for bird communities, to be an appropriate template for similar action within similarly affected and situated ecosystems within the Mediterranean area.

\section{Implications for Practice}

- Birds rapidly colonized the Guadiamar basin after the area was cleaned up and replanted with forest and shrub vegetation that increased the cover and structural complexity of the habitat.

- In similar scenarios to the Guadiamar River spill, adequacy of a restoration program can be evaluated 5-6 years post-restoration.

- When possible, maintain as much of the existing vegetation as possible during spill clean-up efforts for similar bird-recovery programs in Mediterranean-type ecosystems.

- It is possible that the rapid recovery of this spill area post-restoration is a result of the presence of colonizers in surrounding habitat.

\section{Acknowledgments}

We thank Esmeralda Alaminos, Asier Herrero, and Gregorio Moreno-Rueda for assistance with field work and Adela González-Megías and Manolo Pizarro for technical support. David Nesbitt, Steve Busack, and Jenny Brown improved the 
English. Funding for 2001-2002 and 2004-2006 was provided by PICOVER and SECOVER programs, respectively. R.M.-F. was supported by the FP7-REGPOT 2010-1 EcoGenes Project (Grant No. 264125). X.S. was supported by a post-doctoral grant (SFRH/BPD/73176/2010) from Fundação para a Ciência e a Tecnologia (FCT, Portugal). J.C. has a post-doctoral contract jointly financed by the European Social Fund and the Junta de Comunidades de Castilla-La Mancha (Spain) in the framework of the Operational Programme FSE 2007-2013.

\section{LITERATURE CITED}

Abele, L. G., and K. Walters. 1979. The stability-time hypothesis: reevaluation of the data. American Naturalist 114:559-568.

Bibby, J. C., N. D. Burgess, D. A. Hill, and S. Muster. 2000. Bird census techniques. Academic Press, London, United Kingdom.

Buffington, J. M., J. C. Kilgo, R. A. Sargent, K. V. Miller, and B. R. Chapman. 2000. Effects of restoration techniques on breeding birds in a thermallyimpacted bottomland hardwood forest. Ecological Engineering 15: $115-120$

Cárdenas, A. M., and J. M. Hidalgo. 2006. Ecological impact assessment of the Aznalcóllar mine toxic spill on edaphic coleopteran communities in the Guadiamar River basin (Southern Iberian Peninsula). Biological Conservation 15:361-383.

Carrascal, F., A. Gil, C. Montes, and R. Pérez de Guzmán. 2008. La vegetación en la cuenca del Guadiamar y en el Corredor Verde. Pages 283-306 in Juntade Andalucía, editor. La restauración ecológica del Río Guadiamar y el proyecto del Corredor Verde. Dir. Gral. De la Red de Espacios Naturales Protegidos, Consejería de Medio Ambiente, Sevilla, Spain.

Colwell, R. K. 2005. Estimate S: statistical estimation of species richness and shared species from samples. Version 7.5. Persistent URL (available from http://purl.oclc.org/estimates (accessed April 2007).

Delibes, M., S. Cabezas, B. Jiménez, and M. J. González. 2009. Animal decisions and conservation: the recolonization of a severely polluted river by the Eurasian otter. Animal Conservation 12:400-407.

Galán, P. 1996. Colonization of spoil benches of an opencast lignite mine in Northwest Spain by amphibians and reptiles. Biological Conservation 79:187-195.

Gardali, T., A. L. Holmes, S. Small, N. Nur, G. R. Geupel, and G. H. Golet. 2006. Abundance patterns of landbirds in restored and remant riparian forest on Sacramento River, California, U.S.A. Restoration Ecology 14:391-403.

Gaston, K. J., and J. I. Spicer. 1998. Biodiversity: an introduction. Blackwell Science, Oxford, United Kingdom.

Gotelli, N. J., and R. K. Colwell. 2001. Quantifying biodiversity: procedures and pitfalls in the measurement and comparison of species richness. Ecology Letters 4:379-391.

Grimalt, J. O., M. Ferrer, and E. Macpherson. 1999. The mine tailing accident in Aznalcóllar. The Science of Total Environment 242:3-11.

Kobayashi, S. 1982. The rarefaction diversity measurement and the spatial distribution of individuals. Japanese Journal of Ecology 33:101-102.

Lindenmayer, D. B., E. J. Knight, M. J. Crane, R. Montague-Drake, D. R. Michael, and C. A. MacGregor. 2010. What makes an effective restoration planting for woodland birds? Biological Conservation 143:289-301.

Luque, G. M., J. Reyes-López, and J. Fernández-Haeger. 2007. Recovery of ground ant (Hymenoptera: Formicidae) communities six years after a major environmental disaster. Environmental Entomology 36:337-347.

Magurran, A. 2004. Measuring biological diversity. Blackwell Publishing, Oxford, United Kingdom.
Márquez-Ferrando, R., J. M. Pleguezuelos, X. Santos, D. Ontiveros, and J. R. Fernández-Cardenete. 2009. Recovering the reptile community after the mine-tailing accident of Aznalcollar (SW Spain). Restoration Ecology 17:660-667.

Martí, R., and J. C. Del Moral. 2003. Atlas de las aves reproductoras de España. Dirección General de Conservación de la Naturaleza-Sociedad Española de Ornitología, Madrid, Spain.

Meek, C. S., M. D. Richardson, and L. Mucina. 2010. A river runs through it: land-use and the composition of vegetation along a riparian corridor in the Cape Floristic Region, South Africa. Biological Conservation 143:156-164.

Meharg, A. A., D. Osborn, D. J. Pain, A. Sánchez, and M. A. Naveso. 1999. Contamination of Doñana food-chains after the Aznalcóllar mine disaster. Environmental Pollution 105:387-390.

Mills, G. S., J. D. Dunning, and J. B. Bates. 1991. The relationship between breeding bird density and vegetation. The Wilson Bulletin 103:468-479.

Nichols, O. G., and F. M. Nichols. 2003. Long-term trends in faunal recolonization after bauxite mining in the Jarrah forest of southwestern Australia. Restoration Ecology 11:261-272.

Passell, H. D. 2000. Recovery of bird species in minimally restored Indonesian tin strip mines. Restoration Ecology 8:112-118.

Patten, M. A., and J. T. Rotenberry. 1998. Post-disturbance changes in a desert breeding bird community. Journal of Field Ornithology 69:614-625.

PICOVER. 2003. Ciencia y Restauración del Río Guadiamar. Consejería de Medio Ambiente, Junta de Andalucía, Sevilla, Spain.

Purroy, F. J. 1997. Atlas de las Aves de España (1975-1995). SEO/Birdlife. Lynx Edicions, Barcelona, Spain.

Ruíz-Jaén, M. C., and T. M. Aide. 2005. Restoration success: how is being measured? Restoration Ecology 13:569-577.

Scheuhammer, A. M. 1991. Effects of acidification on the availability of toxic metals and calcium to wild birds and mammals. Environmental Pollution 71:329-375.

Solà, C., M. Burgos, A. Plazuelo, J. Toja, M. Plans, and N. Prat. 2004. Heavy metal bioaccumulation and macroinvertebrate community changes in a Mediterranean stream affected by acid mine drainage and an accidental spill (Guadiamar River, SW Spain). Science of the Total Environment 333:109-126.

Suárez-Seoane, S., P. E. Osborne, and J. Baudry. 2002. Responses of birds of different biogeographic origins and habitat requirements to agricultural land abandonment in northern Spain. Biological Conservation 105:333-344.

Ter Braak, C. J. F., and P. Smilauer. 2002. CANOCO reference manual and CanoDraw for Windows user's guide. Software for Canonical Community Ordination (version 4.5). Microcomputer Power, Ithaca, New York, 500 pp.

Wiens, J. A. 1989. The ecology of bird communities. Cambridge University Press, Cambridge, United Kingdom.

\section{Supporting Information}

Additional Supporting Information may be found in the online version of this article:

Appendix S1. Bird species in the Guadiamar Green Corridor during the period 2001-2009. Breeding season observations except ${ }^{*}$ (seen only during winter or during spring/autumn migration); + (breeding species not previously documented in the area).

Please note: Wiley-Blackwell is not responsible for the content or functionality of any supporting materials supplied by the authors. Any queries (other than missing material) should be directed to the corresponding author for the article. 